W.D.R. Writer MB FFARCS FRCPC,

J.B Hurtig MD FRCPC, G. Edelist MD FRCPC,

D. Evans MB FRCPC, G.S. FoX MD FRCPC,

R.E. Needs MB FRCPC,

C.E. Hope MB FFARCS FRCPC,

J.B. Forrest MD PH D FFARCS FRCPC

\section{Epidural morphine prophylaxis of postoperative pain: report of a double- blind multicentre study}

In a double-blind placebo-controlled trial, 154 subjects, having intraperitoneal surgery or Caesarean section, and 53 patients undergoing lower limb orthopaedic surgery, received epidural morphine, $5 \mathrm{mg}$ in $10 \mathrm{ml} 0.9$ per cent $\mathrm{NaCl}$, or placebo, $10 \mathrm{ml} 0.9$ per cent $\mathrm{NaCl}$, intraoperatively to determine duration of action and efficacy in preventing postoperative pain. Epidural morphine gave significantly longer postoperative analgesia $(>11 h)$ than placebo $(3-6 h)$ in both groups $(p<0.05)$ and patients who received morphine required less postoperative analgesic. Obstetric subjects experienced longer pain relief $(18.3 \pm 1.3 \mathrm{~h})$ than patients undergoing non-obstetric intraperitoneal surgery $(9.2 \pm 1.2 \mathrm{~h})$ $(p<0.001)$. Generally mild pruritus affected more than 40 per cent of those receiving morphine, but over 90 per

\section{Key words}

ANALGESIA: postoperative; ANALGESICS: morphine; ANAESTHESIA: obstetric; ANAESTHETIC TECHNIQUES: epidural; PAIN: postoperative.

From the Departments of Anaesthesia, Grace Maternity Hospital, Halifax, Nova Scotia; Ottawa Civic Hospital, Ottawa, Ontario; Mount Sinai Hospital, Toronto, Ontario; Toronto Western Hospital, Toronto, Ontario; Royal Victoria Hospital, Montreal, Quebec; Sunnybrook Medical Centre, Toronto, Ontario; Victoria General Hospital, Halifax, Nova Scotia and McMaster University, Hamilton, Ontario.

Address correspondence to: Dr. W.D.R. Writer, Department of Anaesthesia, Grace Maternity Hospital, Halifax, Nova Scotia B3H 1 W3. cent of obstetric patients receiving morphine. Respiratory depression occurred in 2-7 per cent of subjects who received morphine; unpredictable in onset, it responded rapidly to naloxone. Epidural bupivacaine, if employed for the surgical procedure, appeared to prolong epidural morphine analgesia. We consider epidural morphine useful in preventing postoperative pain, but its use demands close observation of respiratory rate in a high density nursing area.

Several studies report the effectiveness of epidural morphine in the treatment of postoperative pain. ${ }^{1-15}$ While some of these compared the narcotic with a placebo control, ${ }^{6-9}$ and others described administration of the drug before the onset of pain, ${ }^{10-12}$ few trials have combined a placebo control with prophylactic administration of morphine. ${ }^{13-15}$

In order to determine the length of action of epidural morphine, given intraoperatively for prophylaxis of postoperative pain, eight Canadian University Hospitals, with diverse clinical practices, participated in double-blind, randomized, placebo-controlled trials of a preservative-free preparation of the drug. In addition, we sought to determine if epidural morphine diminished the requirement for postoperative analgesia after intraperitoneal or lower limb orthopaedic surgery, and prevented or ameliorated postoperative pain, without unacceptable side effects.

\section{Methods}

The study included two treatment groups enrolled in the participating institutions over a specified time period. One hundred and fifty-four subjects, aged 
TABLE I Patient data

\begin{tabular}{|c|c|c|}
\hline & \multicolumn{2}{|l|}{ Treatment } \\
\hline & Epidural morphine & Placebo \\
\hline Group I & $\mathrm{N}=103$ & $\mathbf{N}=51$ \\
\hline Age (yrs) & $40.8 \pm 1.3$ & $39.2 \pm 1.9$ \\
\hline Height $(\mathrm{cm})$ & $164 \pm 0.9$ & $164.1 \pm 1.1$ \\
\hline Weight (kg) & $72.5 \pm 1.8$ & $70.9 \pm 2.7$ \\
\hline \multicolumn{3}{|l|}{ Sex } \\
\hline Male & $23(22 \%)$ & $12(24 \%)$ \\
\hline Female & $80(78 \%)$ & $39(76 \%)$ \\
\hline *Surgical procedure & $(\mathrm{N}=98)$ & $(\mathrm{N}=45)$ \\
\hline Caesarean section ( \pm tubal ligation) & $28(29 \%)$ & $14(31 \%)$ \\
\hline Cholecystectomy & $20(20 \%)$ & $10(22 \%)$ \\
\hline Gynaccology & $23(23 \%)$ & $10(22 \%)$ \\
\hline Stomach/small bowel & $10(10 \%)$ & $6(13 \%)$ \\
\hline Large bowel & $10(10 \%)$ & $2(5 \%)$ \\
\hline Urology & $3(3 \%)$ & $2(5 \%)$ \\
\hline Other & $4(5 \%)$ & $1(2 \%)$ \\
\hline Group II & $\mathbf{N}=35$ & $N=18$ \\
\hline Age (yrs) & $40.5 \pm 2.5$ & $49.3 \pm 3.8$ \\
\hline Height (cm) & $173.7 \pm 1.6$ & $164.4 \pm 6.1$ \\
\hline Weight (kg) & $76.2 \pm 2.6$ & $77.9 \pm 3.6$ \\
\hline \multicolumn{3}{|l|}{ Sex } \\
\hline Male & $24(69 \%)$ & $13(72 \%)$ \\
\hline Female & $11(3 \mid \%)$ & $5(28 \%)$ \\
\hline *Surgical procedure & $(\mathrm{N}=30)$ & $(N=15)$ \\
\hline Hip joint & $9(30 \%)$ & $5(33 \%)$ \\
\hline Knee joint & $11(37 \%)$ & $3(20 \%)$ \\
\hline Ankle joint & $1(3 \%)$ & $1(7 \%)$ \\
\hline Other (osteotomy etc) & $9(30 \%)$ & $6(40 \%)$ \\
\hline
\end{tabular}

* $N$ = Subjects accepted for analysis.

Values are mean \pm SEM

20 to 70 years, underwent elective intraperitoneal surgery or Caesarean section (Group I), while 53 subjects, aged 19 to 69 years (Group II), had lower limb orthopaedic surgery (Table I). All patients were ASA physical status I or II and each gave informed consent to enter the studies, which were approved by the Human Research Committee in each institution. Patients with chronic obstructive lung disease and associated hypercarbia, severe hepatic disorders or cholestasis, evidence of increased cerebrospinal fluid pressure, obstructive uropathy, suspected allergy or addiction to narcotics, or who were pregnant at the time of planned drug administration, were excluded. No subject took corticosteroids, monoamine oxidase inhibitors, tricyclic antidepressants or clonidine in the two weeks preceding the study. Also excluded were patients having anticoagulant therapy and those with back disorder or suspected obliteration of the epidural space.

For the surgical procedure, patients had general or regional anaesthesia. The choice of technique was determined by the investigator, independent of the study, but no patient received pre- or intraoperative narcotics. Either before or after induction of anaesthesia, an epidural cannula was inserted in an appropriate lumbar interspace for later injection of the study drug or saline placebo, which was given at the time of peritoneal or joint capsule closure using number coded ampoules prepared by A.H. Robins Company. The randomized study design called for a 2:1 allocation ratio of drug to control, and in the two studies 138 subjects received morphine sulphate, $5 \mathrm{mg}$, in $10 \mathrm{ml}$ preservative free 0.9 per cent 
TABLE II Pain intensity rating

\begin{tabular}{lllll}
\hline Rating & None & Mild & Moderate & Severe \\
\hline Description & No pain & $\begin{array}{l}\text { Easily } \\
\text { tolerated }\end{array}$ & $\begin{array}{l}\text { Some discomfort } \\
\text { and continual } \\
\text { awareness of } \\
\text { pain }\end{array}$ & $\begin{array}{l}\text { Considerable } \\
\text { pain causing } \\
\text { marked and } \\
\text { continuous } \\
\text { discomfort }\end{array}$ \\
Score & 0 & 1 & 2 & 3 \\
\hline
\end{tabular}

saline, and 69 had placebo, $10 \mathrm{ml}$ preservative free saline. While a 2:1 allocation loses slightly in sensitivity, it provides more information about subject response and possible side effects. ${ }^{16}$ In addition, such allocation ensures a minimum number of participants receive placebo for their postoperative pain.

After the injection, all patients were continuously observed for $24 \mathrm{~h}$, by research nurses assigned solely to their care. Pulse rate, blood pressure, respiratory rate, and pain intensity, using a simple pain scale (Table II), were recorded at $15-\mathrm{min}$ intervals for $1 \mathrm{~h}$, every $30 \mathrm{~min}$ for the next $11 \mathrm{~h}$, then hourly for a further $12 \mathrm{~h}$. Sleeping patients were not awakened for pulse, blood pressure or pain measurement, but the nurses documented respiratory rate at each observation.

Patients received no postoperative analgesics until they first requested pain relief. They were then given either local anaesthetic via the epidural cannula, or parenteral narcotic, at the discretion of the individual investigator. The interval from the end of surgery to the administration of this first analgesic was noted. Further injections of local anaesthetic or systemic narcotic were given, as requested, for pain. The choice of drug lay with the investigator on each occasion, and some patients received both epidural local anaesthetic and parenteral narcotic in the 24-h study period. To enable comparison of the total analgesic requirement in placebo and treatment groups, all analgesics received by the patient after the onset of postoperative pain, and until completion of the 24-h study period, were expressed as morphine equivalents (meperidine $10 \mathrm{mg}=$ "pantopon" $1.5 \mathrm{mg}=$ morphine $1 \mathrm{mg}$ ), and bupivacaine equivalents (lidocaine $2 \mathrm{mg}$ = lidocaine $\mathrm{CO}_{2} 2 \mathrm{mg}=$ bupivacaine $1 \mathrm{mg}$ ).

All adverse reactions were recorded and classified by the investigator as mild, moderate or severe, on the basis of patient assessment. At the end of the study, investigators rated pain prevention in each patient as poor, fair, good or excellent. Before removing the epidural cannula, its location in the epidural space was confirmed in all subjects by demonstrating an appropriate area of anaesthesia to pinprick, in response to the injection of a local anaesthetic agent.

Data collected from Group I and Group II were analysed separately. The primary variable used for assessment of the drug's efficacy was the time from administration of the study drug to the first postoperative analgesic. This was calculated from data pooled from individual studies, and statistical significance determined using standard 2-factor analysis of variance. Individual studies were also analyzed using parametric (one-sided Student's t-test) and non-parametric methods (one-sided t-test on ranked data).

In a secondary analysis, the investigators' rating of analgesia as good/excellent or fair/poor was compared and the Mantel-Haenszel procedure ${ }^{17}$ used to adjust for the effects of different investigators. Individual investigators' results were analyzed using Fisher's exact one-tailed test.

Adverse effects were tabulated.

\section{Results}

Eleven subjects in Group I (five morphine, six placebo), and eight subjects from Group II (five morphine, three placebo) were withdrawn from analysis, because of non-compliance with the protocol. In Group I, females predominated in treatment and placebo groups, because of the high proportion of obstetrical and gynaecological patients (Table I). We found no other significant differences in age, height, or weight between groups, or between subjects who received morphine and placebo.

Epidural morphine gave significantly longer postoperative analgesia than placebo in both groups 


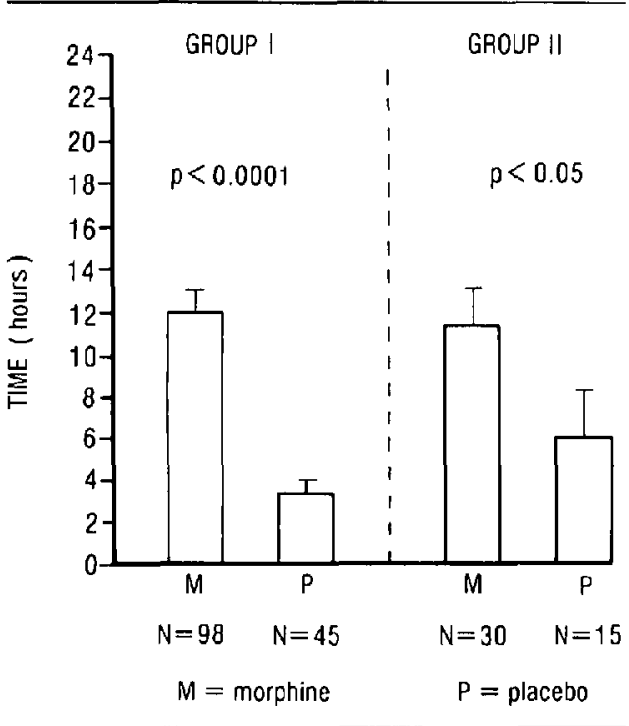

FIGURE 1 Time from administration of study drug to first postoperative analgesic. Bars indicate the mean $\pm S E M$.

(Figure 1). In Group 1, pain relief from morphine lasted $11.7 \pm 1.0 \mathrm{~h}(\mathrm{SEM})$, compared with placebo, $3.3 \pm 0.6 \mathrm{~h}$. Group II morphine recipients remained analgesic for $11.0 \pm 1.6 \mathrm{~h}$, compared with placebo subjects $5.9 \pm 2.2 \mathrm{~h}$. Seventeen Group $\mathrm{I}$ morphine subjects ( 17 per cent), and 4 from Group II ( 13 per cent), required no additional analgesia in the $24 \mathrm{~h}$ study period, and for a variable time thereafter (Figures 2, 3). For the purposes of analysis we assumed a duration of $24 \mathrm{~h}$ analgesia in these

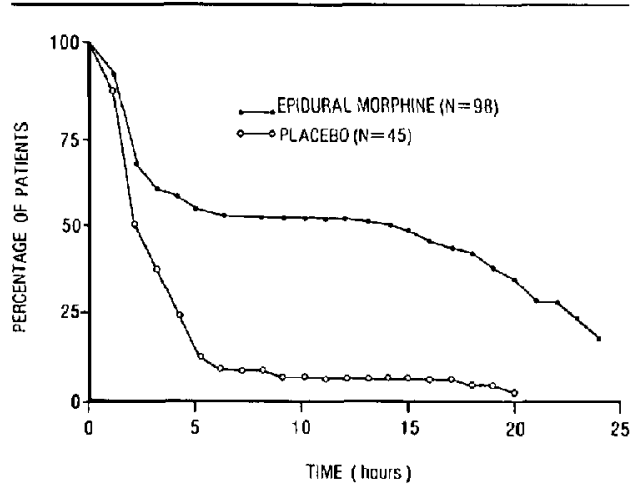

FIGURE 2 Percentage of patients not requiring additional analgesic (group I).

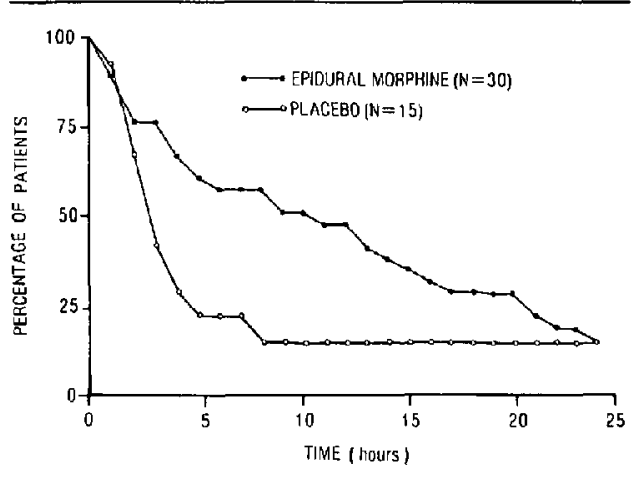

FIGURE 3 Percentage of patients not requiring additional analgesic (group II).

patients, and the value for time to administration of first analgesic therefore underestimates the duration of drug effect. Two Group II placebo recipients also remained pain free for $24 \mathrm{~h}$ (Figure 3 ).

The data for Group I include the results from one centre in which placebo gave longer analgesia than morphine. If these results are removed from the pooled data, the duration of morphine analgesia is $13.3 \pm 1.1 \mathrm{~h}$ in Group I subjects.

Caesarean section patients who received epidural morphine required no additional analgesia for 18.3 $\pm 1.3 \mathrm{~h}$, in contrast to the other abdominal cases in whom this interval was $9.2 \pm 1.2 \mathrm{~h}(\mathrm{p}<0.001)$. All obstetric patients received only regional anaesthesia for the surgical procedure, while the remaining abdominal surgery subjects underwent general anaesthesia, with supplemental regional anaesthesia in 24 cases ( 23 per cent).

In both groups I and II, patients who received morphine required significantly less postoperative analgesics than placebo recipients in the $24 \mathrm{~h}$ study period (Table III). Again, this was more evident in the obstetric subjects.

The investigators' rating of pain prevention confirmed epidural morphine's analgesic effect; over 60 per cent of those having epidural morphine had excellent or good pain relief (Table IV).

Adverse effects occurred in morphine and placebo populations (Table V). Pruritus affected over 40 per cent of morphine recipients in both treatment groups. In more than 70 per cent of cases observers rated the symptom as mild. However, in obstetric subjects pruritus occurred in 93 per cent of those 
TABLE III Narcotic and local anaesthetic requirements in the twenty-four hour study period, expressed as morphine or bupivacaine equivalents (see text).

\begin{tabular}{|c|c|c|c|c|c|c|c|c|c|}
\hline \multirow[b]{3}{*}{$\begin{array}{l}\text { Treatment } \\
\text { group }\end{array}$} & \multicolumn{6}{|c|}{ Abdominal surgery } & \multicolumn{3}{|c|}{ Orthopaedic surgery } \\
\hline & \multirow[b]{2}{*}{$N$} & \multicolumn{2}{|c|}{$\begin{array}{l}\text { All abdominal surgery } \\
\text { (including C-section) }\end{array}$} & \multirow[b]{2}{*}{$N$} & \multicolumn{2}{|c|}{ Caesarean section patients } & \multirow[b]{2}{*}{$N$} & \multicolumn{2}{|l|}{ All patients } \\
\hline & & $\begin{array}{l}\text { Morphine } \\
\text { equivalents } \\
\text { (mg) }\end{array}$ & $\begin{array}{l}\text { Bupivacaine } \\
\text { equivalents } \\
\text { (mg. }\end{array}$ & & $\begin{array}{l}\text { Morphine } \\
\text { equivalents } \\
(m g)\end{array}$ & $\begin{array}{l}\text { Bupivacaine } \\
\text { equivalents } \\
\text { (mg) }\end{array}$ & & $\begin{array}{l}\text { Morphine } \\
\text { equivalents } \\
\text { (mg) }\end{array}$ & $\begin{array}{l}\text { Bupivacaine } \\
\text { equivalents } \\
\text { (mg) }\end{array}$ \\
\hline Epidural & & & & & & & & & \\
\hline $\begin{array}{l}\text { morphine } \\
\text { Placebo }\end{array}$ & $\begin{array}{l}98 \\
45\end{array}$ & $\begin{array}{l}10.4 \pm 1.3 \\
29.1 \pm 3.0\end{array}$ & $\begin{array}{c}60.3 \pm 8.0 \\
132.1 \pm 27.2\end{array}$ & $\begin{array}{l}28 \\
13\end{array}$ & $\begin{array}{l}13.3 \pm 2.9 \\
49.9 \pm 3.0\end{array}$ & $\begin{array}{l}20.0 \pm 3.0 \\
71.3 \pm 12.2\end{array}$ & $\begin{array}{l}30 \\
15\end{array}$ & $\begin{array}{l}18.0 \pm 3.1 \\
25.2 \pm 5.7\end{array}$ & $\begin{array}{l}40.4 \pm 10.2 \\
70.3 \pm 23.4\end{array}$ \\
\hline
\end{tabular}

Values are Mean \pm SEM.

TABLE IV Investigators' end of study evaluation

\begin{tabular}{|c|c|c|c|c|c|c|}
\hline \multirow[b]{3}{*}{ Treatment group } & \multicolumn{3}{|l|}{ Group I } & \multicolumn{3}{|l|}{ Group II } \\
\hline & & \multicolumn{2}{|c|}{ Investigators' rating } & & \multicolumn{2}{|c|}{ Investigators' rating } \\
\hline & & Excellent/good & Fairlpoor & & Excellent/good & Fairlpoor \\
\hline Epidural morphine & $N=98$ & $63(64 \%)$ & $35(36 \%)$ & $\mathrm{N}=30$ & $19(63 \%)$ & $11(37 \%)$ \\
\hline Placebo & $N=45$ & $2(4 \%)$ & $43(96 \%)$ & $N=15$ & $\begin{array}{l}3(20 \%) \\
0<001\end{array}$ & $12(80 \%)$ \\
\hline
\end{tabular}

having morphine. Nausea and vomiting were seen in placebo and morphine patients. Significant differences were evident only with respect to vomiting in Group I morphine subjects. Thirty-four per cent vomited, contrasted with 13 per cent after placebo.

Sixty-seven per cent of all Group II patients experienced urinary retention, compared with 24 per cent in Group I. However, the presence of an indwelling catheter in 128 (89 per cent) Group I subjects, for periods up to $24 \mathrm{~h}$, made assessment of urinary retention difficult in this group. In neither group were clinically significant differences observed between morphine and placebo subjects with respect to urinary retention.

Clinically significant bradypnea occurred in two Group I participants (2 per cent) who received epidural morphine. One developed a respiratory rate of $2-4 / \mathrm{min}$ in the operating room approximately $40 \mathrm{~min}$ after the injection, while another subject developed bradypnea $(9 / \mathrm{min}) 4 \frac{1}{2} \mathrm{~h}$ after epidural morphine. Both patients responded to $0.2 \mathrm{mg} \mathrm{nal-}$ oxone IV, and required no further narcotic antago- nist. Two Group II morphine recipients (7 per cent) also developed bradypnea. In one, the respiratory rate fell to $3 / \mathrm{min}$, after $2 \mathrm{~h} 40 \mathrm{~min}$, and the other experienced bradypnea, $6 / \mathrm{min}, 16 \frac{1}{2} \mathrm{~h}$ after epidural morphine. This patient also received oral triazolam, $0.25 \mathrm{mg}, 1 \frac{1}{2} \mathrm{~h}$ before the bradypnea. Both subjects responded to naloxone. Immediately following surgery, one placebo recipient from each group experienced a clinically significant decrease in respiratory rate, felt to be attributable to anaesthetic factors.

\section{Discussion}

This multicentre study confirms the prevention or amelioration of postoperative wound pain, previously described after the prophylactic administration of epidural morphine. ${ }^{10-12,14.15}$ Although the duration of action we observed in each group compares favourably with similar studies, which report a mean from 6.4 to $26.7 \mathrm{~h},{ }^{6-12,14,15}$ we found considerable variation in mean response from $2.2 \mathrm{~h}$, reported by one investigator, to $18.3 \mathrm{~h}$ in obstetric 
TABLE $V$ Adverse effects

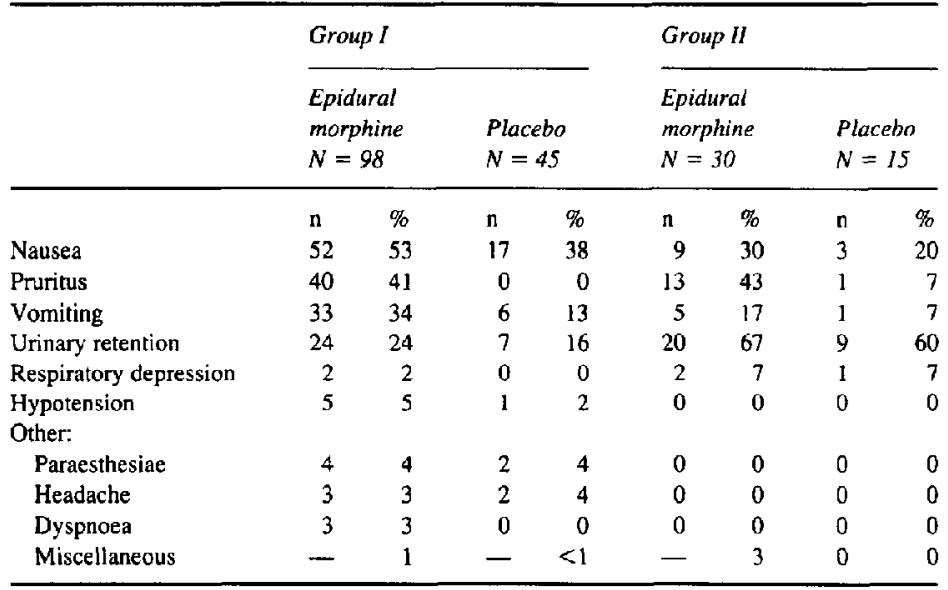

subjects. Early reports suggested a rapid onset of epidural morphine's effect, ${ }^{1,18}$ but later studies document a latency of approximately $30 \mathrm{~min},{ }^{2,5,19}$ and a peak effect at 1 to $3 \mathrm{~h} .{ }^{5,19}$ We found that non-obstetric Group I patients, with poor or fair analgesia from epidural morphine, required their first postoperative analgesic $1.7 \pm 0.1 \mathrm{~h}$ after the end of surgery. Comparable placebo subjects required pain relief after $1.8 \pm 0.2 \mathrm{~h}$. Since the protocol forbade the use of other pre- or intraoperative narcotics, it would appear these epidural morphine recipients experienced significant early postoperative pain, before the drug reached its peak effect. However, they had a longer interval between their first and second postoperative analgesics, $2.9 \pm 0.8 \mathrm{~h}$, and longer duration of analgesia (range $0.05-18.0 \mathrm{~h}$ ), than placebo subjects, $1.4 \pm 0.2 \mathrm{~h}$ $(0.08-4 \mathrm{~h})$. This perhaps suggests a longer latency of epidural morphine's onset, since it appeared to enhance the effect of later systemic analgesics, although insufficient by itself to alleviate the immediate postoperative pain. Group II epidural morphine subjects, with poor or fair pain relief, required postoperative analgesics after $3.5 \pm 1 \mathrm{~h}$, compared with their placebo counterparts, $2.4 \pm$ $0.3 \mathrm{~h}$. They also demonstrated a longer interval between the first and second postoperative analgesics, $6.4 \pm 2.0 \mathrm{~h}$, than placebo recipients $2.4 \pm$ $0.5 \mathrm{~h}$. Despite the classification as fair or poor responses, these figures suggest the epidural morphine in this group exerted some beneficial effect on immediate postoperative pain and potentiated later systemic analgesics.

The obstetric patients had strikingly longer pain relief than other abdominal surgery cases. However, the mean duration of $18.3 \mathrm{~h}$ was less than reported in other Caesarean section studies (22$29 \mathrm{~h}), 5,8,15$ but underestimates the actual duration because we assumed a maximum of $24 \mathrm{~h}$ pain relief in mothers who required no additional analgesia. Ten of the obstetric morphine recipients (36 per cent) required no other analgesia in the $24 \mathrm{~h}$ after the drug was given.

Bupivacaine, 0.75 per cent, was used as the principal local anaesthetic for the Caesarean section, and this may explain the better pain relief. The obstetric placebo recipients remained pain free for $4.2 \pm 0.4 \mathrm{~h}$. We may hypothesise that continuing analgesia from the bupivacaine allowed time for epidural morphine, in the treatment subjects, to reach its peak effect. Although bupivacaine 0.75 per cent is no longer recommended for obstetric anaesthesia, 0.5 per cent provides similarly lengthy analgesia. ${ }^{20}$ Kotelko ${ }^{21}$ recently reported poor postoperative analgesia from epidural morphine after chloroprocaine anaesthesia for Caesarean section, presumably because of its shorter duration and rapid block regression. In contrast, parturients receiving bupivacaine, 0.75 per cent, had good to excellent pain relief from epidural morphine. Lanz et al. ${ }^{14}$ in orthopaedic patients, reported better postoperative analgesia from epidural morphine, when associated 
with bupivacaine anaesthesia, than with mepivacaine. Other authors have noted an apparent prolongation of local anaesthetic effect by epidural morphine, ${ }^{22,23}$ although Brooks et al. ${ }^{24}$ could not confirm this in Caesarean section subjects. Our findings appear to underscore the benefits of regional anaesthesia with bupivacaine for the surgical procedure.

Some authors have reported a segmental effect of epidural narcotics, ${ }^{2,13}$ but we found no significant difference in duration of morphine between those having upper and lower abdominal procedures, when obstetric patients were excluded.

Pruritus also occurred more commonly in parturients. This reflects the experience of others with the obstetric population, ${ }^{5,15}$ although the reported incidence varies widely in pregnant and non-pregnant subjects. ${ }^{10,11,14,25,26}$ Scott and Fischer ${ }^{27}$ consider opiate pruritus an enkephalinergic itch reflex, initiated at the spinal level, and we may speculate the pregnancy induced increase in endogenous opioids $^{27}$ perhaps lowers the threshold for this opiate effect. Pruritus was usually mild in both groups.

Of interest in Group II subjects was the apparently high incidence of urinary retention, 67 per cent for morphine patients and 60 per cent in placebo subjects. The routine catheterization of many Group I patients may have obscured a higher incidence of urinary retention in these subjects, and makes comparison of the two groups invalid.

Respiratory depression from epidural narcotics is well described, multifactorial, ${ }^{29-34}$ and appears to be related to rostral spread of the drug..$^{26.29}$ With less lipophilic narcotics, such as morphine, it occurs most frequently $4-12 \mathrm{~h}$ after injection, but may persist up to $24 \mathrm{~h} .{ }^{29,30}$ Clinically, respiratory depresion may be evident as bradypnea or apnea ${ }^{31}$ or may remain undetected, ${ }^{32}$ but sensitive measurements of pulmonary ventilation and $\mathrm{CO}_{2}$ response ${ }^{29.31-34}$ reveal the significant and prolonged depression of central respiratory regulation. ${ }^{29,34}$

We measured only respiratory rate, and documented respiratory depression when the investigator felt the bradypnea to be clinically significant. The incidents of bradypnea we observed occurred between $40 \mathrm{~min}$ and $16 \frac{1}{2} \mathrm{~h}$ after the injection, and they emphasise the unpredictability and individual variability of this effect. ${ }^{33}$ Possible causes included potentiation of epidural morphine by anaesthetic drugs, systemic analgesics or triazolam. We cannot exclude the possibility of clinically undetectable respiratory depression in other cases.

The close surveillance of patients, by nurses solely assigned to their care, is an expense few hospitals can afford. ${ }^{35}$ However, the use of epidural narcotics requires close monitoring of respiratory rate for 24 hours, ${ }^{29,30,35}$ immediate availability of trained staff able to provide airway management and ventilatory support, and facilities for oxygenation, suction and the intravenous administration of naloxone. ${ }^{30,34}$ In addition, the prescription of systemic narcotics, and CNS depressants, must be withheld if analgesia is adequate. ${ }^{30}$ Such facilities can best be provided in an ICU environment, recovery room, or high-dependency, step-down area. ${ }^{35}$

The preservative-free morphine preparation we studied recently became available in Canada. We consider it useful in the management of postoperative pain after major abdominal or lower limb surgery, especially following epidural anaesthesia with bupivacaine. However, the occurrence of side effects, and the possibility of unpredictable respiratory depression, require close patient surveillance and may limit its routine use. Further studies may help determine optimum standards for postoperative care and the prevention and management of adverse effects.

\section{Acknowledgements}

The authors gratefully acknowledge the assistance and generous support of A.H. Robins Company, Richmond, Virginia, who provided the Epimorph and placebo employed in this study. In particular, we thank Dr. Samuel Tisdale Jr., Mr. Stephen O'Dell and Dr. Michael Boyd for providing the medical information, project co-ordination and statistical analysis, which greatly facilitated this multicentre trial. This work could not have been undertaken without the help of the research nurses in each centre. We especially thank Sandra Matheson, Ruth Ann Leib, Susan Ruddick, Karen Yeger, Shirley Gauthier, Natalie Dragaloski and MaryHelen Blacknall.

\section{References}

1 Behar M, Magora $F$, Olshwang D, Davidson JT. Epidural morphine in treatment of pain. Lancet 1979; 1: 527-8. 
2 Bromage PR, Camporesi E, Chestnut D. Epidural narcotics for postoperative analgesia. Anesth Analg 1980; 59: 473-80.

3 Rawal $N$, Sjostrand $U$, Dahlstrom $B$. Postoperative pain relief by epidural morphine. Anesth Analg 1981; 60: 726-31.

4 Anderson I, Thompson WR, Varkey GP, Knill RL. Lumbar epidural morphine as an effective analgesic following cholecystectomy. Can Anaesth Soc J. 1981; 28: 523-9.

5 Rosen MA, Hughes SC, Shnider SM et al. Epidural morphine for the relief of postoperative pain after cesarean delivery. Anesth Analg 1983; 62: 666-72.

6 McClure JH, Chambers WA, Moore E, Scon DB. Epidural morphine for postoperative pain. Lancet 1980; 1 : 975-6.

7 Holland AJ, Srikantha SK, Tracey JA. Epidural morphine and postoperative pain relief. Can Anaesth Soc J 1981; 28: 453-7.

8 Caombs DW, Danielson DR, Pageau MG, Rippe E. Epicurally administered morphine for post-cesarean analgesia. Surg Gynecol Obstet 1982; 154: 385-8.

9 Martin R, Salbaing J, Blaise G, Tétraulr JP. Tétrault $L$. Epidural morphine for postoperative pain relief: a dose response curve. Anesthesiology 1982; 56: 423-6.

10 Rawal N, Sjostrand UH, Dahlstrom B, Nydahl P-A, Ostelius $J$. Epidural morphine for postoperative pain relief: a comparative study with intramuscular narcotic and intercostal nerve block. Anesth Analg 1982; 61: 93-8.

11 Barron DW, Strong JE. Postoperative analgesia in major orthopaedic surgery. Epidural and intrathecal opiates. Anaesthesia 1981; 36: 937-41.

12 Scheinin B, Rosenberg PH. Effect of prophylactic epidural morphine or bupivacaine on postoperative pain after upper abdominal surgery. Acta Anaesthesiol Scand 1982; 26: 474-8.

13 Asari H, Inoue K, Shibaia T, Soga T. Segmental effect of morphine injected into the epidural space in man. Anesthesiology 1981; 54: 75-7.

14 Lanz E, Theiss D, Riess W, Sommer U. Epidural morphine for postoperative analgesia: A doubleblind study. Anesth Analg 1982; 61: 236-40.

15 Carmichael FJ, Rolbin SH, Hew EM. Epidural morphine for analgesia after Caesarean section. Can Anaesth Soc J 1982; 29: 359-63.

16 Friedman $L M$, Furberg CD. De Mets DL. Fundamentals of clinical trials. 1st ed. Boston: John Wright, 1981: 40-57.
17 Mantel $N$, Haenszel $W$. Statistical aspects of the analysis of data from retrospective studies of disease. Journal of the National Cancer Institute 1959; 22: 719-48.

18 Dirksen R, Nijhuis GM. Epidural opiate and perioperative analgesia. Acta Anaesthesiol Scand 1980; 24: $367-74$

19 Thompson WR, Smith PT, Hirst M. Varkey GP, Knill RL. Regional analgesic effect of epidural morphine in volunteers. Can Anaesth Soc J 1981;28: $530-6$

20 Bramage $P R$. Epidural analgesia. 1st ed. Toronto: WB Saunders, 1978: 307.

21 Kotelko DM, Thigpen JW, Shnider SM, Foutz SE, Rosen MA, Hughes SC. Postoperative epidural morphine analgesia after various local anesthetics. Anesthesiology 1983; 59: A413.

22 Magora F, Olshwang D, Eimerl J et al. Observations on extradural morphine analgesia in various pain conditions. Br J Anaesth 1980; 52: 247-52.

23 Writer WD, James FM III, Wheeler AS. Doubleblind comparison of morphine and bupivacaine for continuous epidural analgesia in labor. Anesthesiology 1981; 54: 215-9.

24 Brooks GZ, Donchin Y, Collins JG, Kitahata LM, Jefferson SA. Epidural morphine does not affect the duration of action of epidural 2-chloroprocaine following Caesarean section. Can Anaesth Soc $J$ 1983; 30: 598-602.

25 Torda TA, Pybus DA. Comparison of four narcotic analgesics for extradural analgesia. $\mathrm{Br} \mathrm{J}$ Anaesth 1982; 54: 291-5.

26 Bromage PR, Camporesi EM, Durant PA, Nielsen $C H$. Rostral spread of epidural morphine. Anesthesiology 1982; 56: 431-6.

27 Scott PV, Fischer HB. Spinal opiate analgesia and facial pruritus: a neural theory. Postgrad Med J 1982; 58: 531-5.

28 Genazzani $A R$, Facchinetti $F$, Parrini $D$. $\beta$-Lipotrophin and $\beta$-endorphin plasma levels during pregnancy. Clin Endocrinol 1981; 14: 409-18.

29 Knill RL, Clement JL, Thompson WR. Epidural morphine causes delayed and prolonged ventilatory depression. Can Anaesth Soc J 1981; 28: 537-43.

30 Martin R, Lamarche Y, Tétrault JP. Epidural and intrathecal narcotics. Can Anaesth Soc J 1983; 30: $662-73$.

31 Bromage PR, Camporesi EM, Durant PA, Nielsen $C H$. Influence of epinephrine as an adjuvant to 
epidural morphine. Anesthesiology 1983; 58 : 257-62.

32 Holland RB, Levitt MW, Whitton LA, Shadbolt $N$ Carbon dioxide response after epidural morphine. Anaesthesia 1982; 37: 753-7.

33 Doblar DD, Muldoon SM, Albrecht PH, Baskoff J, Watson RL. Epidural morphine following epidural local anaesthesia: effect on ventilatory and airway occlusion pressure responses to $\mathrm{CO}_{2}$. Anesthesiology 1981; 55: 423-8.

34 Rawal $N$, Wallwil $M$. Respiratory depression after epidural morphine - an experimental and clinical study. Anesth Analg 1984; 63: 8-14.

35 Bromage PR. The metamorphosis of regional anesthesia. Reg Anesth 1984; 9: 109-18.

\section{Résumé}

Dans une étude à double insu contrôlée avec un placebo, 154 sujets devant subir une chirurgie intrapéritonéale ou une césarienne, et 53 patients devant subir une chirurgie orthopédique sur les membres inférieurs, ont reçu une injection épidurale de morphine $5 \mathrm{mg}$ dans $10 \mathrm{ml} 0.9$ pour cent $\mathrm{NaCl}$ ou du placebo $10 \mathrm{ml} 0.9$ pour cent $\mathrm{NaCl}$ lors de l'opération afin de déterminer la durée de l'action et l' efficacité de prévenir les douleurs post-opératoires. La morphine en injection épidurale procura une analgésie post-opératoire d'une durée significarivement plus longue $(>11 \mathrm{~h})$ que le placebo $(3-6 \mathrm{~h})$ chez les deux groupes $(p<0.05)$. Les patients ayant reçu la morphine ont aussi requis moins d'analgésie post-opératoire. Le groupe obstétrical a profité d'une plus longue analgésie $(18.3 \pm 1.3 \mathrm{~h})$ que les patients subissant la chirurgie intrapéritonéale non obstétricale $(9.2 \pm 1.2 \mathrm{~h})(\mathrm{p}<$ $0.001)$. Un prurir en général léger a affecté 40 pour cent et plus des patients ayant reçu la morphine mais pour le groupe obstétrical ce pourcentage était supérieur à 90 pour cent. La dépression respiratoire survint chez 2-7 pour cent des sujets ayant reşu la morphine. L'apparition de cette dépression respiratoire n' était pas prévisible et répondait rapidement d l'administration de naloxone. L'administration de bupivacaine par voie epidurale si employée pour la procédure chirurgicale semble pro. longer l'analgésie fournie par la morphine épidurale. On considère que l'administration de morphine par voie épidurale est utile pour prévenir la douleur post-opératoire mais son utilisation demande une surveillance accrue de la fréquence respiratoire dans des locaux où les soins infirmiers sont denses. 